\title{
SIGNIFICANCE OF CHROMITE, G5 Mg-ALMANDINE GARNET, ZIRCON AND TOURMALINE IN HEAVY MINERAL DETECTION OF DIAMOND BEARING LAMPROITE
}

Fipke, Charles $E$.

\author{
C.F. Mineral Research Ltd., 263 Lake Ave., Kelowna, B.C., Canada VIY 5W6
}

A project, with the objective of identifying heavy minerals that could be utilized in heavy mineral prospecting programs to detect diamondiferous lamproite, was completed by the Geological Survey of Canada and C.F. Mineral Research Ltd. consultants in 1990.

The project involved ball milling, heavy mineral concentrating and S.E.M. micro analysing of all heavy mineral species from large $(30-180 \mathrm{~kg})$ rock samples from the Argyle (AT) Australia, the Prairie Creek (PC) Arkansas, and the Jack (JK) B.C., Canada, diamondiferous lamproites.

Potential abrasion resistant heavy indicator minerals identified in the foregoing samples were similarly concentrated and analyzed using bulk rock samples from the following diatremes: the Ellendale 4 (EL4) diamondiferous lamproite, Australia; the Smoky Butte (SB) lamproite, Montana, U.S.A.; the Sloan 1 (SL) diamondiferous kimberlite, Colorado, U.S.A.; the Presidente Olegario (PO2, P03) and satellite (P01) possible lamproitic diatremes, Brazil; the Sover (SV) and the New Elands kimberlites, South Africa; and from Canada - the Larry (LR), the Mark (MR) and the Mike (MK) lamproitic diatremes, B.C.; the Batty (BT), N.W.T., the Crossing Creek (CC), B.C., the Joff (JF), B.C., the Kirkland Lake (KL), Ont., the Sturgeon Lake (SK), Sask., barren and diamondiferous kimberlites; the Blackfoot (BF), B.C., the HP (HP), B.C., the Ile Bizard (IB), Que., alkaline lamprophyres; and the Mountain (MD) olivine melilitic diatreme, N.W.T.

The indicator minerals recovered and analyzed from the foregoing diatremes as well as world wide diamond inclusion mineral compositions were computer classified. The classifications used were adapted from Dawson and Stephens (1975\&1977) and R. Moore's (1990) methods of classifying garnets and clinopyroxenes ("Cpx") so that J. Gurney's (1985) method of classifying G10 composition garnets was included and minerals of regional " $\mathrm{R}$ " compositions excluded.

Table 1 illustrates that only three "E" eclogitic and three "P" peridotitic garnets were recovered from $32 \mathrm{~kg}$. of the most diamondiferous sandy tuff phase of Argyle (AT); similarly, only two " $\mathrm{E}$ " and three "P" garnets were recovered from $42 \mathrm{~kg}$. of the most diamondiferous phase of Prairie Creek (PC). Low counts were similar for the Jack (JK) but substantially higher for the E1lendale 4 (EL/4) diamondiferous lamproite. Although significant quantities of $\mathrm{Cpx}$ wère recovered from (PC) and (EI4) only three Cpx (classified according to Dawson's methods) were recovered from the (AT) sample and four Cpx from the (JK) sample. It is thus probable that the Argyle and Jack lamproites would be bypassed by prospecting surveys based only on results of "P" and "E" garnets and Cpx.

Table 1 illustrates that chromites, G5 garnets, zircons and tourmaline are the most abundant abrasion resistant heavy minerals present in concentrates from all dianondiferous lamproites sampled - ( AT, EL4, PC, JK ). A summary of characteristics of these minerals is as follows:

CHROMTTES from diamondiferous lamproite tend to be euhedral to slightly rounded and/or broken, opaque black to translucent brown colored grains that commonly exhibit grey alteration frosting of outer rims. Table 1 illustrates that between $1.5 \%$ (for PC) and 12\% (for AT) of the chromites analyzed have $>60 \%$ Cr203. Most of these plot within the diamond inclusion and intergrowth fields of $\mathrm{MgO}-\mathrm{Cr} 203$, A1203-Cr203, and Cr203-TiO2 (figure 1). Figure 1 illustrates that non-diamond inclusion chromites from diamondiferous lamproites (and kimberlites) have enriched $\mathrm{Cr} 2 \mathrm{O} 3$ and Ti02 compared to a file of 821 chromite analyses from volcanic, ophiolite, 
alpine and layered ultranafic sources. Some chromites from the P01 diatreme situated near Presidente Olegario, Brazil, plot within the enriched Cr203-TiO2 field.

G5 Mg-ALMANDINE GARNETS recovered from diamondiferous lamproite exhibit pink to purple or pale brown coloration and tend to exhibit broken or anhedral form, thought to be a result from milling of megacrystic forms. Although these garnets typically classify as "R" regional garnets by $R$. Moore parameters, a search of publications did not identify any regional rocks as sources for these G5 garnets of $\mathrm{FeO}<29.94 \%$ other than kimberlite or lamproite. Table 1 (bottom) demonstrates that seven garnets, included in diamond, classified as G5. While such G5 garnets could be useful in some regional heavy mineral prospecting prograns to locate lamproite and kimberlite they are non discriminating between barren and diamondiferous as illustrated in table 1 (note barren SB count).

DIATREME ZIRCONS appear to differ from round xerocystic zircons from sandstone wallrocks by the presence of glassy to frosted textures typical of "E" and "P" garnets and by the absence of abrasion textures characteristic of clastic rounded zircons. These tiny $(<0.5 \mathrm{~mm})$ mostly round to spherical, purple to brown colored, non fluorescent zircons and pink to honey colored orange fluorescent (to UV) zircons were recovered from 22 of the 23 diatremes tested. Such zircons, in some cases, contain concentric overgrowths of dark purple or pink zircon on round light zircon cores. Lead isotopes dates to 1856 MY have been obtained from round zircons from the Prairie Creek and to 2685 MY from the Jack lamproites. Levels of up to $0.16 \mathrm{~K} 20$ and $1.7 \% \mathrm{MgO}$ have been detected in zircons recovered from diamondiferous lamproite.

DIA'TREME TDURMALINES are characteristically unzoned, exhibit glassy to frosted textures typical of "E" and "P" garnets and typically lack abrasion surface textures. Minor to abundant quantities of round to rounded, light translucent brown to opaque brown dravitic tourmaline was recovered from all diamondiferous lamproite tested (AT, EI_, PC and JK) but was significantly absent from the Smoky Butte (SB) barren lamproite and most other diatremes tested (Table 1). Fifty four out of fifty nine (92\%) diatreme tourmalines microprobe analyzed to date contain (33.7-37.4\%) $\mathrm{SiO2},(28.1-35.3 \%) \mathrm{Al} 203,,<0.15 \% \mathrm{Cr} 203,<0.22 \% \mathrm{MnO},(2.9-13.0 \%) \mathrm{FeO},(>1.0-8.8 \%)$ $\Lambda 1203,<0.15 \% \mathrm{TiO},(1.3-2.3 \%) \mathrm{Na} 20,(>0.05-2.0 \%) \mathrm{CaO},<10.7 \% \mathrm{~B} 203,<0.55 \% \mathrm{~F}$ and $<0.3 \%$ C.L. Thirty nine out of a file of 164 regional tourmalines (from world wide literature sources) also classify within the foregoing compositional limits of diatreme tourmalines. Figure 2, a TiO2 - K2O compositional plot of the 54 diatreme and 39 regional tourmalines, demonstrates that 30 of 39 total tourmalines from diamondiferous lamproite (77\%) and 7 of 164 total regional tourmalines (4\%) plot in a field of elevated TiO2 - K2O. None of the diatreme tourmalines, from non-diamondiferous pipes, plot within the elevated TiO2 - K2O field.

The presence of dravitic tourmaline of elevated TiO2 - K2O in diamondiferous lamproite (and kimberlite(SK)), as well as the common presence of CP8 jadetic diopside included in worldwide diamond inclusions but absence of CP8 clinopyroxene in worldwide diamondiferous lamproite and kimberlite (refer to table 1) can be explained by a reaction similar to the following:

$$
\text { [ kyanite ] }
$$

or

olivine [SiO2+corun] D.I. (CP8) jadetic diopside $\mathrm{Mg}(\mathrm{Mg}, \mathrm{Fe}) \mathrm{SiO} 4+\mathrm{B}^{+3} 2\left(\mathrm{H}^{+1}\right)+\mathrm{Cl}^{-1}+\mathrm{F}^{-1}+(\mathrm{OH})^{-1}+\mathrm{B}_{204^{-2}+3}[\mathrm{SiO} 2+\mathrm{Al} 2 \mathrm{O} 3]+(\mathrm{K}, \mathrm{Na}, \mathrm{Ca})(\mathrm{Mg}, \mathrm{Fe}, \mathrm{Ti})(\mathrm{Si}, \mathrm{Al}) 206$
$=(\mathrm{Na}, \mathrm{K})(\mathrm{Mg}, \mathrm{Fe}, \mathrm{Ca}, \mathrm{Ti}) 3 \mathrm{~A} 16 \mathrm{~B} 3 \mathrm{Si} 6027(\mathrm{OH}, \mathrm{F}, \mathrm{Cl}) 4$

The above reaction would necessitate olivine-rich kimberlitic or lamproitic magmas charged with boron and weak acid gases to react on intrusive contact with jadetic diopside and kyanite or corundum (with excess SiO2) constitutes of diamond 
bearing Group I eclogite to form dravitic tourmaline. Boron is a minor constitute of some kimberlite and lamproite matrixes as well as a trace constitute of blue colored diamonds (Fipke et al,1990).

R. Moore (1986) has demonstrated that the arithmetic mean of $\mathrm{K} 20$ and of $\mathrm{TiO} 2$ in Group I eclogitic clinopyroxenes is 0.08 and 0.58 respectively ,compared with 0.02 and 0.33 for Group II eclogit.ic clinopyroxenes not associated with diamond formation. The above reaction does not necessitate the presence of $\mathrm{K}$ in $\mathrm{Cpx}$, therefore it is possible that a similar reaction with low (K20-TiO2) Cpx from non diamond bearing Group II eclogite may have produced the low (K20-TiO2) dravitic tourmalines detected from pipes not known to contain diamond. The absence of tourmaline could perhaps be related to low activities of magmatic boron. The elevated $\mathrm{K} 20-\mathrm{TiO} 2$ levels preserved in dravitic tourmaline from diamondiferous lamproite would be enhanced by buffering effects of high activities of $\mathrm{K}$ and $\mathrm{Ti}$ present in lamproite magmas.

Regardless of paragenesis, round tourmalines and zircons have been utilized to detect lamproites in the southeast Rocky Mountains of British Columbia, because such minerals are absent from stream sediments derived from the regional stratigraphy.

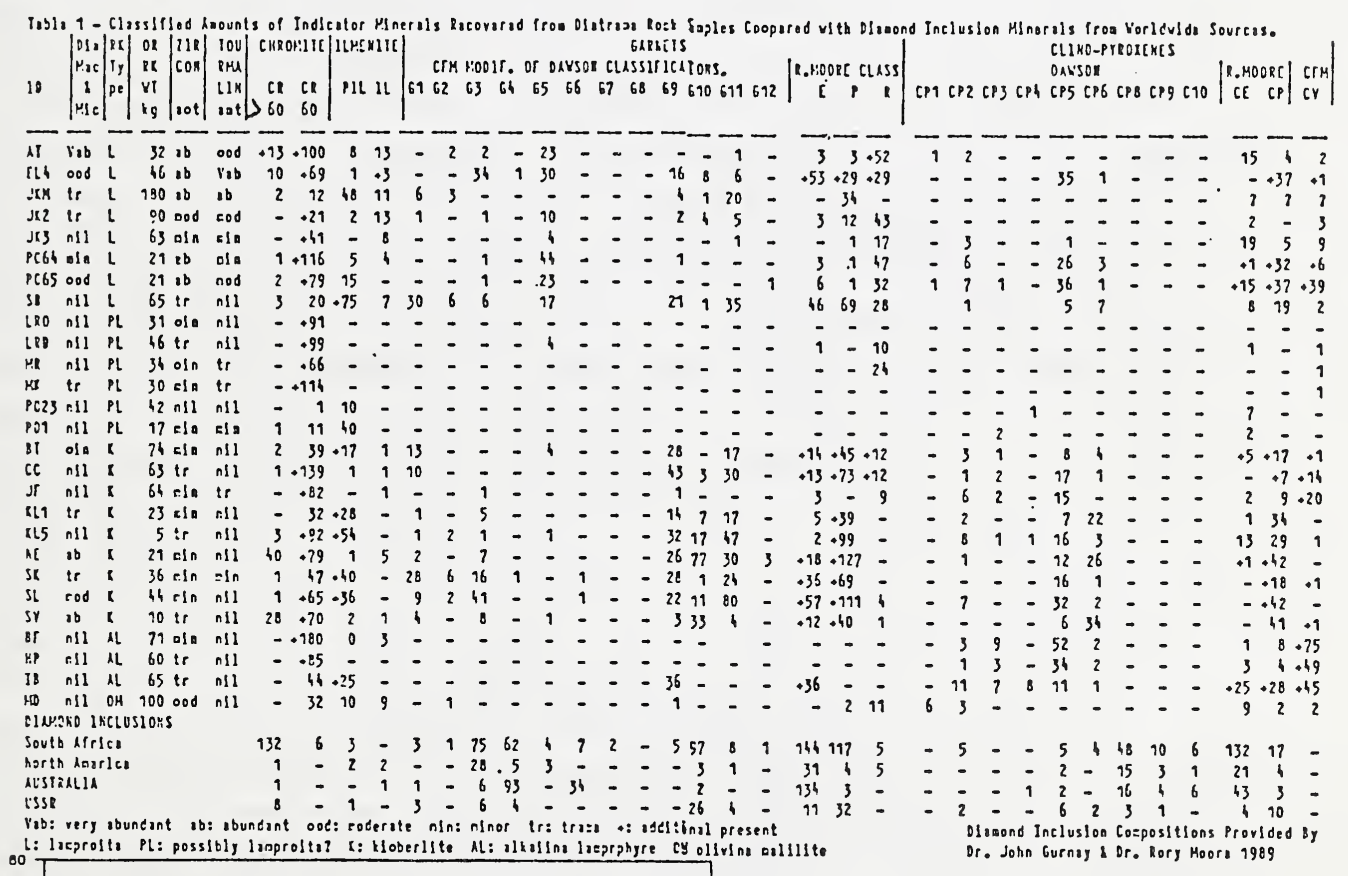

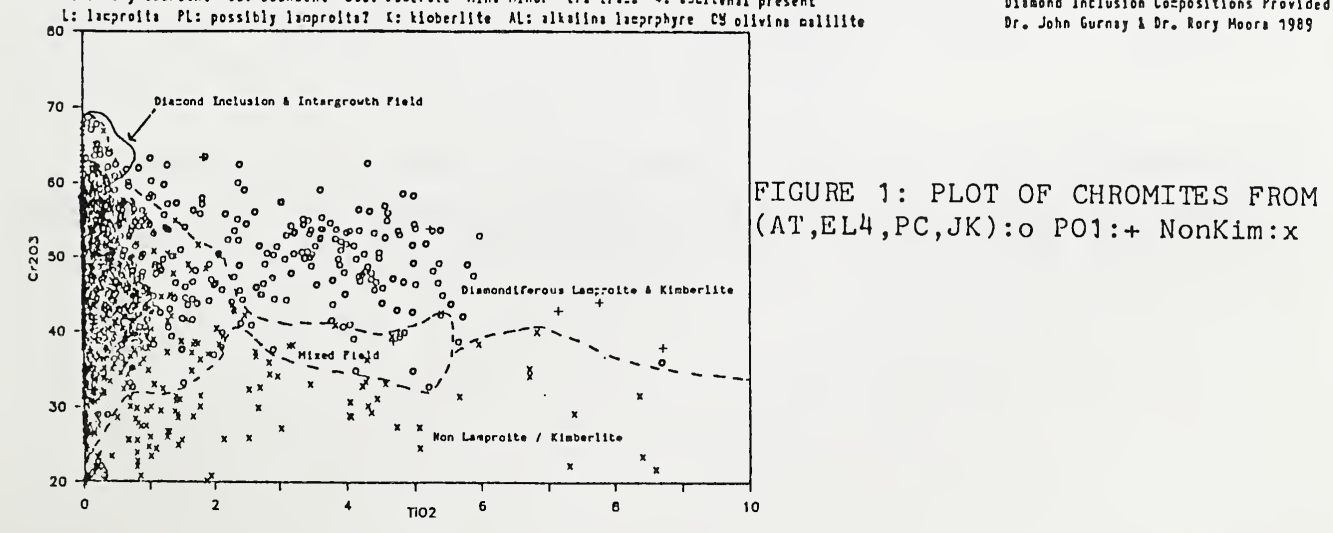




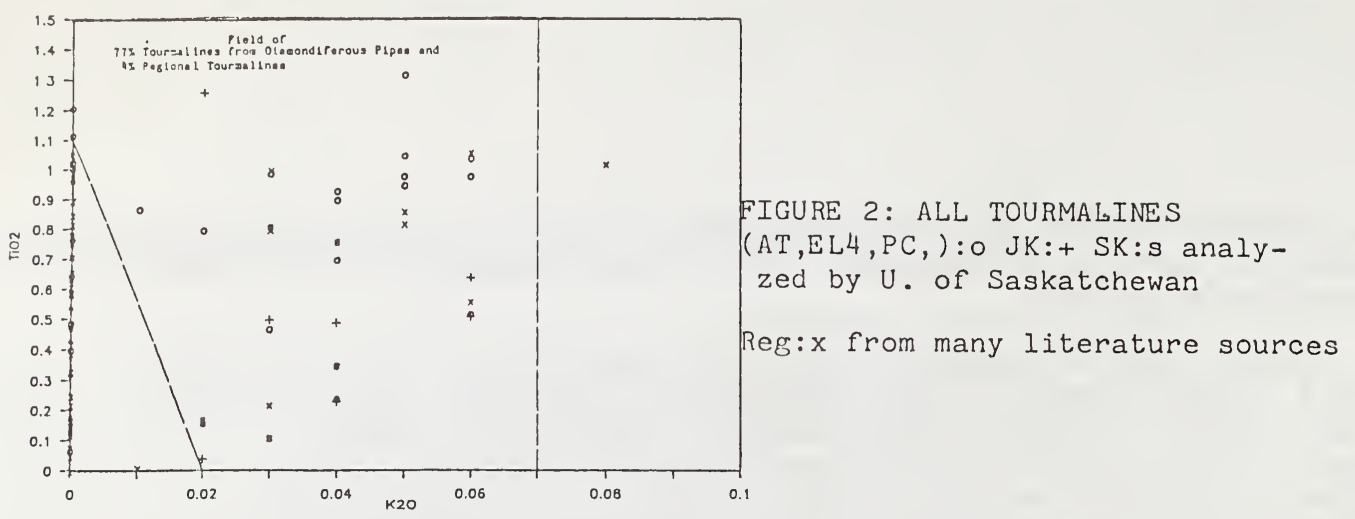

DAKSOM, J.B., and STEPHEIIS, H.C.(1975)Statlistlcal ClassLfIcatlon of Garnets fron KImberllte and Assoclated Xenollths, Journal of Geology, vol.83, p.589-607

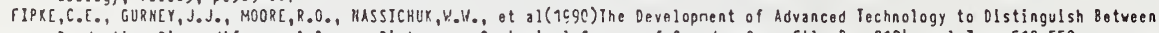

Productive Dlamondiferous \& Aarron Dlatremes, Geologlcal Survey of Canada, Open file Rep.2124, vol.3, p.518-550
GuRner, J.J.(1985)A Corrolation betwoen Garnets and Dianonds In KInberlites, KInberlites Occurronco and OrIgln: 1 Basls for Conceptual Hodels in Exploratlon, The Unlversity of Vestern Australla, Publlcation Ho.8, p.143-166

HOORE,R.0.(1986)A Study of the Kimberiltes, Dlamonds \& Assoclated Rocks \& IIInerals from the Monastery MIne, S.A., Pho Thesls, Unlverslty of Cape Town, vol.2, 0.22

SIEPKEIIS, h'.E., and DAYISON, J.B. (1977)Statlstlcal Comparlson Betveen Pyroxenes from XInberlltes and Thelr Assoclated Xenollths, Journal of Goology, v01.85, $0.433-449$ 